\title{
PERCEPTION OF INTELLECTUAL \\ CAPITAL AND ITS IMPACT ON BUSINESS SUSTAINABILITY: EVIDENCE FROM SMALL, MEDIUM, AND LARGE ENTERPRISES
}

\author{
Elwira Gross-Gołacka1, Marta Kusterka-Jefmańska², \\ Paulina Spałek ${ }^{3}$, Bartłomiej Jefmański ${ }^{4}$
}

\footnotetext{
1 University of Warsaw, Faculty of Management, Department of Organization Theory and Methods, Poland, ORCID: 0000-0003-4863-9391, egross@wz.uw.edu.pl;

2 Wrocław University of Economics and Business, Faculty of Management, Department of Quality and Environmental Management, Poland, ORCID: 0000-0002-6773-6157, marta.kusterka@ue.wroc.pl;

3 Warsaw School of Economics, Poland, ORCID: 0000-0002-0355-1217, ps55696@doktorant.sgh.waw.pl;

4 Wrocław University of Economics and Business, Faculty of Economics and Finance, Department of Econometrics and Computer Science, Poland, ORCID: 0000-0002-0335-0036, bartlomiej.jefmanski@ue.wroc.pl.
}

\begin{abstract}
The main goal of this article is to analyze the level of differentiation of awareness and knowledge among managers of small, medium and large enterprises in the scope of the essence and meaning of intellectual capital as well as the influence of its elements on the sustainable development of enterprises in Poland. Intellectual capital is perceived as a key resource of an enterprise. It is also one of the most valuable resources of an enterprise, which enables its sustainable development. It is critical base of organization's innovative and strategic sustainability. This article is based around the results of a survey conducted in 2019 among 1,067 enterprises operating in Poland. For the purposes of the verification of the statistical hypothesis, the classical chi-squared test of independence has been applied along with the analysis of variations for fuzzy numbers (FANOVA) with an assumed level of significance $\alpha=0.05$. The assessment of the influence of the elements of intellectual capital on the sustainable development of enterprises has been conducted with the application of fuzzy conversion scales. In fuzzy conversion scales, points are most often expressed as triangular or trapezoidal fuzzy numbers. The conducted research indicates a difference between theory and practice in the field of intellectual capital management among enterprises in Poland. On the one hand managers declare awareness of the importance of the influence of intellectual capital on the development of enterprises in Poland, whereas on the other hand, a significant majority of them state that they have not implemented an intellectual capital management strategy at their enterprises and neither identify nor measure this capital or its elements.
\end{abstract}

Keywords: Intellectual capital of enterprises, business sustainability, fuzzy measurements, fuzzy conversion scales, FANOVA.

JEL Classification: C12, C38, C81, C83, D81, J24, O34.

APA Style Citation: Gross-Gołacka, E., Kusterka-Jefmańska, M., Spałek, P., \& Jefmański, B. (2021). Perception of Intellectual Capital and Its Impact on Business Sustainability: Evidence from Small, Medium, and Large Enterprises. E\&M Economics and Management, 24(2), 35-50. https://doi.org/10.15240/tul/001/2021-2-003 


\section{Introduction}

In the modern world, one of the key factors of success of an organization is intellectual capital. A dynamically changing external environment exerts pressure on enterprises to implement innovative solutions, products and services. The value created to a lesser degree depends on the possessed tangible assets, compared to the value of intangible ones. Intellectual capital resources are established as the basis for the level of competitiveness of an organization in the 21st century by among others Bounfour and Edvinsson (2005), Cabrita and Vaz (2006). Currently, competitive advantage is determined by unique recourses, which are difficult to reproduce by the competition. Intellectual capital is thus more and more often perceived as a key resource of an enterprise. It is also one of the most valuable resources of an enterprise, which enables its sustainable development. It is critical base of organization's innovative and strategic sustainability (Bontis, 2002; Bontis et al., 2000). It is comprised of human capital, structural capital and relational capital. Sustainable development of enterprises, also known as business sustainability, can be understood as a practical implementation of goals and rules of the concept of sustainable development on a microeconomic level. It requires management and coordination of all aspects of enterprise activity: social, environmental, and financial to ensure responsible, ethical, environmentally friendly, and profitable in long-term success. Business sustainability is a strategy that integrates social, economic, and environmental principles into the business model.

The main goal of the article is to analyze the level of differentiation of awareness and knowledge of managers of small, medium and large enterprises within the scope of the essence and meaning of intellectual capital and the influence of its elements on the sustainable development of enterprises in Poland.

In the paper, a systematic literature review of selected articles was made. In the field of empirical studies, survey research was held. In the field of data analysis, statistical methods were used.

The structure of the article covers three sections. Section 1: Theoretical Background explains essential from this study's scope definitions - intellectual capital and business sustainability. It also presents the key findings of the literature review. Section 2: Research
Methodology describes the statistical method applied. Section 3: Results covers a brief presentation of some general statistics and results. Conclusions summarize the research results.

\section{Theoretical Background}

According to Roos and Roos (1997), intellectual capital is defined as a collection of intangible assets (resources, capabilities and competitiveness), which influence the effectiveness of an organization and value creation. The literature discusses different classifications of intellectual capital. Examples are works published by Edvinsson and Malone (1997) or Stewart (2001). Often referred to is the division of intellectual capital into three subsets: human capital, structural capital and relational capital. Between these elements there is a strong relationship, characterized by a feedback loop. From the perspective of managers, in order to create value, it is essential to connect these three elements together. In this context, intellectual capital is a phenomenon of interaction, transformation and complementation. As such, the effectiveness of one resource can improve based on investing in others. Thus, the value of the enterprise created based on intellectual capital is an effect of the activity of each of its sub-elements. Hence, it is essential to properly manage intellectual capital at enterprises, in a way which takes into account its identification, measurement, development and protection.

The concept of sustainability has been associated with Wes Jackson's work on agriculture (Jackson, 1980) and initially formulated in the Brundtland Report, WCED (1987). Barbieri et al. (2010) observe that business sustainability can be understood in the conventional manner, i.e. as the capacity to create resources to remunerate the factors of production, replace assets that have been used, and invest to continue competing. Munck et al. (2016) observe that in the business scenario, countless concepts have been proposed to enable discussion of management processes for organizational sustainability. From this perspective, both academics and business consultants see a need to better understand which practices are necessary for the management models to meet and encompass the premises of the concept of sustainability. From a business point of view, sustainability connotes three dimensions: 
economic, social and environmental (Sheth et al., 2011). The economic dimension of sustainability refers to companies' ability to create value and improve financial performance. Social dimension of sustainability describes the consideration of societal issues like tolerance toward others or equal rights and focuses on the well-being of people and communities as a noneconomic form of wealth (Choi \& $\mathrm{Ng}, 2011)$. The last dimension of sustainability, namely, environmental refers to the maintenance of natural capital (Goodland, 1995).

Also, there is evidences that socioeconomic development, with environmental equilibrium and the integration of intellectual capital, leads to the gradual development of a favorable organizational ecosystem. Knowledge based and intangible issues have risen to the forefront of interest for those attempting to understand and improve organizational capabilities for sustainable firm performance and value creation (e.g. Drucker, 1988; Grant, 1996). Mertins and Orth (2012) consider intangible resources to be of central importance to sustainable development of firms. In order to implement management of sustainability, these authors consider that it is crucial for firms to use knowledge efficiently, thereby improving their potential for innovation.

Theoretical aspects and application ones related to intellectual capital have appeared in academic discourse relatively recently, but nonetheless, both in Polish and international literature, publications discussing this field can be found. In frames of the empirical scope, only in the last five years, several publications have emerged, which present results of studies on intellectual capital. One of them is the publication by Arshad and Arshad (2018), which focuses on the influence of intellectual capital on the performance of small and medium textile enterprises located in Pakistan. The authors by means of their research, based on a group of 350 enterprises, have proven that intellectual capital significantly impacts the performance of textile enterprises. The influence of intellectual capital on the performance on small and medium enterprises is also discussed in the article by Abdullah and Othman (2019). The authors of the paper, based on the results of research conducted in Malaysian food and beverage SMEs, have proven that good management of employees' knowledge adds value to the firms and makes them competitive in the market economy. The research results have also made it possible to identify moderate positive correlations between compensation and reward on one hand and organizational performance on the other. Research into intellectual capital has also been conducted by Aymen et al. (2019), who have indicated a relation between the integration of intellectual capital and the success of small and medium enterprises in Iran. Based on the opinion of 217 employees of small and medium enterprises, the authors have developed a model of success of an enterprise and have later proven that the success of small and medium enterprises is dependent on the integration of intellectual capital and the rotation of young finance department personnel. The analysis of the relation between intellectual capital and productivity of small and medium enterprises has been discussed in the publication by Todingbua et al. (2018). The analysis utilizes the results of a survey among owners of small and medium enterprises in Makassar. The results of the study have proven that managerial skills have a significant impact on the productivity of SMEs in Makassar. Furthermore - as part of the empirical scope research is also conducted into the relationship between intellectual capital and innovativeness of enterprises. An example of this type of a publication is the article by Khan et al. (2018), in which the authors analyze the influence of intellectual capital on the product, process and administration innovation in the SMEs. The research was conducted among 318 small and medium enterprises operating in Australia and representing different branches of the economy. Research into intellectual capital has also been conducted by Aseanty (2016). Through this research has been estimated the relationship between intellectual capital (which is proxies through the dimension of human capital, namely skill, innovativeness, competency, and knowledge) to the sustainability of SMEs in Central Java, Indonesia. Multiple regression analysis indicated that skill is the most important antecedent of overall sustainability of SMEs in Central Java. The results revealed strong, positive and significant relationship between all the independent variables to the sustainability of SMEs in Central Java, implying that highly human capital leads to higher overall sustainability in SMEs in Central Java.

As stated earlier, intellectual capital is essential for sustainability business. Based on 
Tab. 1: The key findings of the literature review

\begin{tabular}{|c|c|}
\hline The key findings of the literature review & Authors \\
\hline $\begin{array}{l}\text { - Intellectual capital is a foundation of } \\
\text { sustainable growth and competitive } \\
\text { advantage. } \\
\text { - Intellectual capital (overall) has significant and } \\
\text { positive impact on business sustainability. }\end{array}$ & $\begin{array}{l}\text { Chen et al., 2006; Chen, 2008; Akhtar et al., 2015; } \\
\text { Omar et al., 2017; Xu \& Wang, 2018; Massaro } \\
\text { et al., 2018; Suciu \& Năsulea, 2019; Mukherjee \& } \\
\text { Sen, 2019; Dal Mas, } 2019\end{array}$ \\
\hline $\begin{array}{l}\text { - Structural capital has a significantly positive } \\
\text { impact on business sustainability. }\end{array}$ & Wasiluk, 2013; Yusoff et al., 2019 \\
\hline $\begin{array}{l}\text { - Human capital has a significantly positive } \\
\text { impact on business sustainability. }\end{array}$ & Hayton, 2005; Claver-Cortés et al., 2015 \\
\hline $\begin{array}{l}\text { - Relational capital has a significantly positive } \\
\text { impact on business sustainability. }\end{array}$ & Xu \& Wang, 2018; Yusoff et al., 2019 \\
\hline $\begin{array}{l}\text { Economic, social and environmental domains } \\
\text { of sustainability have a positive direct effect } \\
\text { on corporate reputation which is one of the } \\
\text { key components of relational capital. }\end{array}$ & $\begin{array}{l}\text { Martinez García de Leaniz \& Rodríguez del } \\
\text { Bosque, 2013; Cowan \& Guzman, } 2020\end{array}$ \\
\hline $\begin{array}{l}\text { - Firms having higher intellectual capital } \\
\text { efficiency perform better. } \\
\text { - Intellectual capital and company performance } \\
\text { are positively related. The more intangible- } \\
\text { intensive companies present a better financial } \\
\text { long-term performance-profitability and return, } \\
\text { financial sustainability) - than the others. }\end{array}$ & $\begin{array}{l}\text { Chen et al., 2005; Pew Tan et al., 2007; Rehman } \\
\text { et al., 2012; Sumedrea, 2013; Aji \& Kurniasih, } \\
\text { 2015; Arifin, 2016; Mondal, 2016; Jordão \& } \\
\text { Almeidy, 2017; Nassar, } 2018\end{array}$ \\
\hline $\begin{array}{l}\text { The impact of the elements of intellectual } \\
\text { capital on business sustainability varies, } \\
\text { depending on their size. }\end{array}$ & Chen, 2008; Akhtar et al., 2015 \\
\hline
\end{tabular}

Source: own

the literature review it cannot be unequivocally stated, which of its elements have the greatest impact on business sustainability. As such, based on the discussed research, it can be stated that there are diverse (Tab. 1).

On the other hand, few researchers (Firer \& Williams, 2003; Shiu, 2006; Pew Tan et al., 2007; Maditinos et al., 2011; Mehralian et al., 2012; Dženopoljac et al., 2016) found a negative relationship or no relationship between IC and firm's performance (Mukherjee \& Sankar Sen, 2019).

\section{Research Methodology}

The main goal of the conducted research has been the analysis of the dependency between the size of an enterprise in Poland measured by the number of employees and the following aspects related to managing intellectual capital:

- knowledge about the concept of intellectual capital;
- possessing an intellectual capital management strategy;

- measuring intellectual capital and/or its elements;

- the influence of elements of intellectual capital on sustainable development of enterprises in Poland.

The analysis utilizes the results from a study on managing intellectual capital by enterprises in Poland. The research was conducted in May 2019. The research was realized through the CATI and CAWI methods in a representative group of 1,067 enterprises operating in Poland (employing at least 10 employees) with an assumed level of trust of 0.95 and an estimation error of $3 \%$. It was based on a proportional selection of enterprises based on voivodeships and their size measured by the number of employees. The assumed structure of the test group also took into account the differentiation of enterprises based on their type of activity (the number of interviews conducted was 
proportional to the participation of enterprises in different PKD sections [Polish Classification of Activities]). The structure of the research sample was created based on data from Central Statistical Office dated January 2019. The interviews were conducted with representatives of the management level of the enterprises in question.

For the purpose of the analysis of the correlation between the size of an enterprise and its knowledge of intellectual capital, measuring intellectual capital, as well as possessing an intellectual capital management strategy, the classical chi-squared test of independence was utilized, with an assumed level of significance $\alpha=0.05$.

In the measurement of the importance of each element of intellectual capital with regards to the sustainable development of enterprises, a four-level scale was used, with each level being respectively described by "definitely insignificant", "insignificant", "significant", "very significant". In the construction of the measurement tool, it has also been provided that respondents could answer "difficult to say", if they were unable to definitely determine the influence of elements of intellectual capital on the development of their enterprises. The measurement scale applied in the survey is a type of a Likert scale, which are most often utilized in gathering opinions and attitudes of respondents. These scales, while being attractive and easy-to-follow for respondents, also have their limitations. According to Steven's theory, the analysis of the results of the measurement utilizing ordinal scales only allows for a relationship between the majority and minority as well as the counting of instances. This means the obtained results cannot be directly used to analyze the dependency between observing the influence of the elements of intellectual capital on the sustainable development of enterprises and their size. It is also more difficult to determine which elements of intellectual capital have, in the opinion of respondents, the largest influence on the development of enterprises. This results from the fact that in the case of ordinal scales it is not possible to average the results, especially in the case of a small number of levels constituting the scale. In order to overcome these limitation it had been decided that for the purpose of statistical analysis and verification of research hypotheses, a transformation will be applied of the measurement scale to the form of fuzzy sets, resulting in fuzzy conversion scales. Such a step made it possible to average the results in accordance with arithmetical operations, which are allowed in the case of fuzzy numbers presented for instance in the following publications: Klir and Yuan (1995), and Chen and Pham (2001). In the article it has been proposed to utilize the fuzzy conversion scale proposed by Lubiano et al. (2016).

Averaging the importance assessment results allowed for the construction of the ranking of the influence of the elements of intellectual capital on the sustainable development of enterprises in Poland, as perceived by the respondents, i.e. of the managers partaking in the survey. It should be noted that in accordance with the methodology of arithmetic operations on triangular fuzzy numbers, the result - which was an arithmetical mean - also had the form of a triangular fuzzy number. The direct comparison of the two averages expressed in such a form is not possible, therefore in such a case it is necessary to apply the so-called defuzzification of fuzzy numbers. The result of this defuzzification is a real number, which, among other things, allows to arrange the mean values of the significance assessment in order from highest to lowest. In the article the two most commonly utilized methods have been applied, which are related to the defuzzification of triangular fuzzy numbers, namely: the center of gravity (CoG) and the median. The application of two methods was aimed at eliminating the element of bias in the selection of the method of defuzzification and determining the validity of the obtained order of mean values. In the case of observed discrepancies in the obtained rankings, their concordance coefficient was estimated using Kendall's tau rank.

The transformation of results into the form of fuzzy numbers, which has been proposed in this paper, has also made it possible to analyze the variance of triangular fuzzy numbers (FANOVA), which allowed for investigating the significance of the differences between the average assessments of the importance of the influence of elements of intellectual capital on the sustainable development of enterprises in Poland, differentiated based on their size. The FANOVA method verifies the hypothesis (Parchami et al., 2017):

$$
H_{0}: \tilde{\mu}_{1}=\tilde{\mu}_{2}=\ldots=\tilde{\mu}_{r},
$$




$$
H_{1}: \text { not all } \tilde{\mu}_{i}^{\prime} s(i=1, \ldots, r) \text { are equal. }
$$

where $\tilde{\mu}_{i}$ is the average value of the characteristic expressed in the form of a triangular fuzzy number for the $i$-th group.

For calculations, this article utilizes the ANOVA. TFNs package, developed by Parchami (2018). For the purpose of verification of the hypothesis described in this paper, a level of significance of $\alpha=0.05$ has been assumed.

\section{Results}

\subsection{Knowledge of the Concept of Intellectual Capital in Enterprises in Poland}

The results of the study indicate that the concept of intellectual capital is known to nearly $70 \%$ of the surveyed enterprise managers in Poland. Representatives of large enterprises employing between 250 and 999 employees (82\% of responses) proved to be particularly familiar with this issue. In the case of small and medium-sized enterprises, $67 \%$ and $68 \%$ of respondents answered positively to the question asked. In order to assess the relationship between the size of the enterprise and knowledge of the concept of intellectual capital, the following research hypotheses were formulated:

$H_{0}$ : The size of the enterprise measured by the number of employees does not have an impact on the knowledge of the concept of intellectual capital.

$H_{1}$ : The size of the enterprise measured by the number of employees has an impact on the knowledge of the concept of intellectual capital.

In order to verify the null hypothesis, the chi-squared test of independence was used. The value of test statistic was equal to $x^{2}=2.19$ at a critical level of significance $p$-value $=0.335$. The obtained result shows that there are no grounds to reject the null hypothesis, which means that the size of the enterprise does not significantly affect the knowledge of the concept of intellectual capital by enterprise managers in Poland.

\subsection{The Presence of Intellectual Capital Management Strategies at Enterprises in Poland}

Despite that in many enterprises in Poland the concept of intellectual capital is known, only in a fraction of them has the strategy of intellectual capital management been developed and implemented. The results of the study showed that $22 \%$ of small enterprises declared the functioning of such a strategy, in the case of medium-sized enterprises $-30 \%$, and among large companies $28 \%$. In order to assess the relationship between the size of an enterprise and having an intellectual capital management strategy, the following research hypotheses were formulated:

$H_{0}$ : The size of the enterprise measured by the number of employees does not have an impact on possessing an intellectual capital management strategy.

$H_{1}$ : The size of the enterprise measured by the number of employees has an impact on possessing an intellectual capital management strategy.

The value of test statistics was equal to $x^{2}=3.451$ at a critical level of significance $p$-value $=0.178$.

The obtained result shows that there are no grounds for rejecting the null hypothesis, which means that the size of the enterprise does not have an impact on possessing an intellectual capital management strategy.

\subsection{Measuring the Intellectual Capital at Enterprises in Poland}

The results of measuring the intellectual capital may constitute the basis for a comprehensive enterprise valuation and support decisionmaking regarding, among other things, investing in intangible assets. Ongoing monitoring of the level of intellectual capital and its elements allows for their optimization and a better understanding of the relationships between them. Measurement of intellectual capital also allows to increase employees' awareness of their role in the company and creating value.

Despite the significance of intellectual capital for the development and competitiveness of enterprises, and measurement tools welldescribed in literature, the results seem to indicate that the vast majority of enterprises located in Poland do not measure intellectual capital and/or its elements. It is worth observing that the measurement of intellectual capital and/or its elements is more often declared by small enterprises employing up to 50 employees than medium and large enterprises. Detailed results are presented in Fig. 1. 


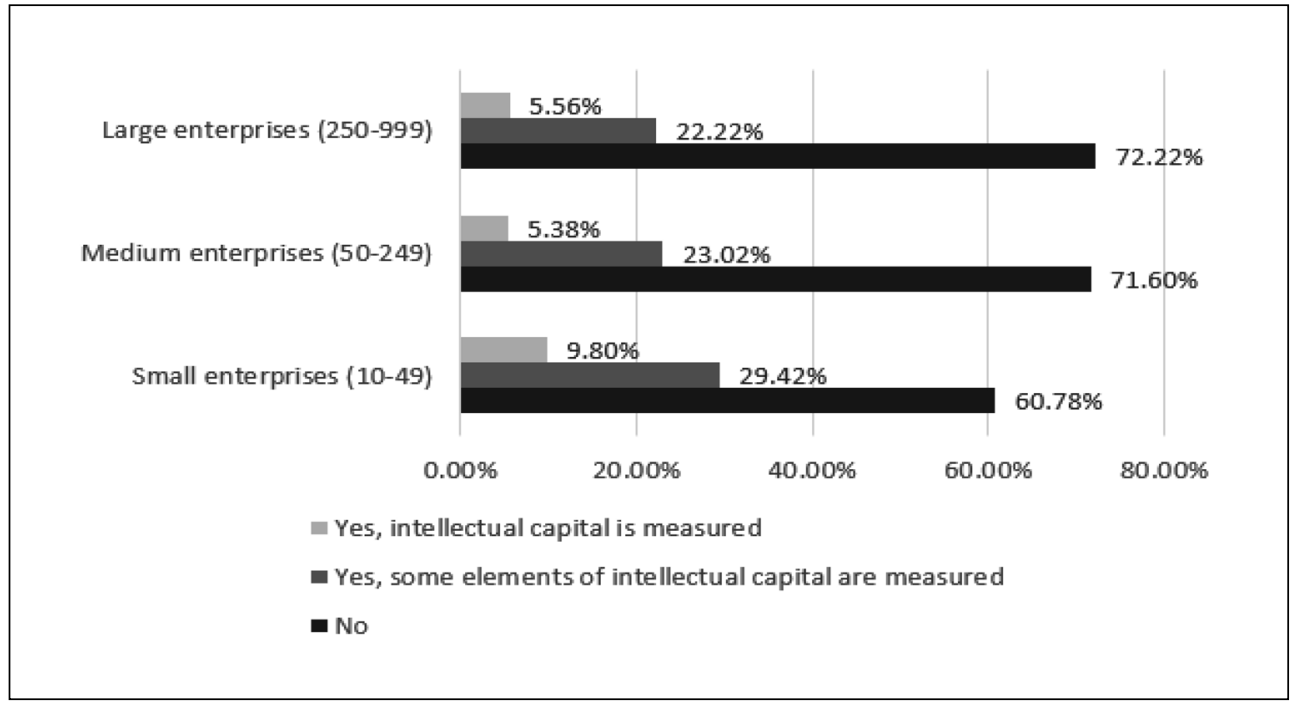

Source: own

In order to assess the relationship between the size of an enterprise and whether it measures intellectual capital and/or its elements, the following research hypotheses were formulated:

$H_{0}$ : The size of the enterprise measured by the number of employees does not have an impact on it measuring intellectual capital and/or its components.

$H_{1}$ : The size of the enterprise measured by the number of employees has an impact on it measuring intellectual capital and/or its components.

The value of test statistics was equal to $x^{2}=5.815$ at a critical level of significance $p$-value $=0.213$.

The obtained result shows that there are no grounds to reject the null hypothesis, which means that the size of the enterprise does not have an impact on it measuring intellectual capital.

\subsection{The Significance of the Elements of Intellectual Capital in Shaping the Sustainable Development of Enterprises}

The assessment of the significance of the impact of the elements of intellectual capital on the sustainable development of enterprises was carried out through its division into three components of intellectual capital, among which the following were specified:

- human capital: $\mathrm{H} 1$ - employee knowledge, H2 - employee skills, H3 - creativity and innovativeness of employees, $\mathrm{H} 4$ - employee motivation, $\mathrm{H} 5$ - employee experience, $\mathrm{H} 6$ - employee integrity, $\mathrm{H} 7$ - employee honesty, H8 - ability to work in a team, $\mathrm{H} 9$ - ability and willingness of employees to share knowledge and information, $\mathrm{H} 10$ - employee satisfaction, $\mathrm{H} 11$ - employee involvement, $\mathrm{H} 12$ - employee well-being, $\mathrm{H} 13$ - health;

- structural capital: S1 - technical infrastructure, S2 - information resources/ systems and databases, S3 - intellectual property (patents, licenses, trademarks), S4 - organizational culture, S5 - processes and management methods;

- relational capital: R1 - customer loyalty and satisfaction, R2 - customer participation in creating products/services, R3 - investor relations, R4 - relations with science and research units, $\mathrm{R} 5$ - relations with suppliers, R6 - reputation and image of the enterprise on the market. 


\section{Business Administration and Management}

Detailed parameters of fuzzy triangular numbers (a - left spread of fuzzy number, b - the center of a fuzzy number area, c - right spread of fuzzy number) for factors of human, structural and relational capital have been respectively presented in Tab. A1-A3 in the Appendix.

In the next stage of the analysis, the relationship between the size of the enterprise and the perception of the significance of the impact of individual elements of intellectual capital on the sustainable development of enterprises has been examined. For each of the elements of intellectual capital, the following research hypotheses have been verified:

$H_{0}$ : The size of the enterprise measured by the number of employees does not have an impact on the assessment of the significance of a given element of intellectual capital in shaping the sustainable development of the enterprise.

$H_{1}$ : The size of the enterprise measured by the number of employees has an impact on

\section{Tab. 2: Details of ANOVA for intellectual capital components}

\begin{tabular}{|c|c|c|c|}
\hline $\begin{array}{l}\text { Intellectual capital } \\
\text { elements }\end{array}$ & $\tilde{F}$-statistic & $P$-value & Test result \\
\hline \multicolumn{4}{|c|}{ Human capital } \\
\hline $\mathrm{H} 1$ & 1.242 & 0.289 & Accept $H_{0}$ \\
\hline $\mathrm{H} 2$ & 0.139 & 0.870 & Accept $H_{0}$ \\
\hline $\mathrm{H} 3$ & 0.253 & 0.776 & Accept $H_{0}$ \\
\hline $\mathrm{H} 4$ & 0.181 & 0.834 & Accept $H_{0}$ \\
\hline $\mathrm{H} 5$ & 3.151 & 0.043 & Reject $H_{0}$ \\
\hline $\mathrm{H} 6$ & 4.642 & 0.009 & Reject $H_{0}$ \\
\hline $\mathrm{H} 7$ & 0.585 & 0.558 & \multirow{7}{*}{ Accept $H_{0}$} \\
\hline $\mathrm{H} 8$ & 1.282 & 0.278 & \\
\hline $\mathrm{H} 9$ & 0.165 & 0.848 & \\
\hline $\mathrm{H} 10$ & 2.515 & 0.081 & \\
\hline $\mathrm{H} 11$ & 0.510 & 0.600 & \\
\hline $\mathrm{H} 12$ & 0.487 & 0.615 & \\
\hline $\mathrm{H} 13$ & 2.322 & 0.099 & \\
\hline \multicolumn{4}{|c|}{ Structural capital } \\
\hline $\mathrm{S} 1$ & 1.803 & 0.165 & \multirow{2}{*}{ Accept $H_{0}$} \\
\hline S2 & 0.944 & 0.390 & \\
\hline S3 & 2.112 & 0.121 & Accept $H_{0}$ \\
\hline S4 & 3.077 & 0.047 & Reject $H_{0}$ \\
\hline S5 & 1.308 & 0.271 & Accept $H_{0}$ \\
\hline \multicolumn{4}{|c|}{ Relational capital } \\
\hline $\mathrm{R} 1$ & 4.336 & 0.013 & Reject $H_{0}$ \\
\hline $\mathrm{R} 2$ & 2.023 & 0.133 & Accept $H_{0}$ \\
\hline R3 & 2.085 & 0.125 & Accept $H_{0}$ \\
\hline R4 & 5.973 & 0.003 & Reject $H_{0}$ \\
\hline R5 & 0.068 & 0.934 & Accept $H_{0}$ \\
\hline
\end{tabular}


the assessment of the significance of a given element of intellectual capital in shaping the sustainable development of the enterprise.

The FANOVA method was used as the average importance assessments have been expressed in the form of fuzzy triangular numbers in the analysis of the relationship between the size of the enterprise and the perception of the significance of the impact of selected elements of intellectual capital on the sustainable development of enterprises. Tab. 2 presents the value of test statistics $\tilde{F}$, the $p$-value and the decision regarding the lack of grounds for, or the rejection of the null hypothesis for each of the elements of intellectual capital.

The results of the hypothesis verification indicated that in most cases the size of the enterprise does not affect the assessment of the importance of the impact of intellectual capital elements on achieving their sustainable development. Significant differences were observed for 5 components: employee experience and integrity, organizational culture, customer loyalty and satisfaction, relations with science and research units.

In accordance with the methodology adopted in the article, identifying the most important elements of intellectual capital, according to managers, that have an impact on the sustainable development of enterprises - required the use of fuzzy conversion scales. Possessing significance assessments of the elements of intellectual capital expressed in the form of fuzzy triangular numbers, it was possible to calculate mean significance scores using fuzzy number arithmetic. Since the average significance ratings are also expressed in the form of fuzzy triangular numbers, they have been defuzzified in accordance with the CoG and median methods. Due to a large number of elements of intellectual capital, in order to facilitate the comparison of significance assessments, individual elements have been given rank according to the principle that the higher the average value, the higher the rank. The ranks assigned to the elements of intellectual capital have been specified in Tabs. 3-5.

Selecting the method of defuzzification of the averages of fuzzy numbers did not have a significant impact on the distribution of the levels assigned to the elements of intellectual capital. Slight differences have been observed only in the case of levels assigned to elements of the human capital in the group at small and

\section{Tab. 3: Ranking of the influence of elements of human capital on the sustainable development of enterprises in Poland}

\begin{tabular}{c|c|c|c|c|c|c}
\multirow{2}{*}{$\begin{array}{c}\text { Human capital } \\
\text { elements }\end{array}$} & \multicolumn{6}{|c|}{ Size of enterprise } \\
\cline { 2 - 8 } & \multicolumn{2}{|c|}{ Small } & \multicolumn{2}{c}{ Medium } & \multicolumn{2}{c}{ Large } \\
\cline { 2 - 8 } & CoG & Median & CoG & Median & CoG & Median \\
\hline $\mathrm{H} 1$ & 4 & 4 & 3 & 3 & 1 & 1 \\
\hline $\mathrm{H} 2$ & 3 & 3 & 2 & 2 & 2 & 2 \\
\hline $\mathrm{H} 3$ & 13 & 11 & 10 & 10 & 8 & 8 \\
\hline $\mathrm{H} 4$ & 7 & 7 & 5 & 5 & 5 & 5 \\
\hline $\mathrm{H} 6$ & 9 & 9 & 12 & 12 & 10 & 11 \\
\hline $\mathrm{H} 7$ & 2 & 2 & 4 & 4 & 7 & 7 \\
\hline $\mathrm{H} 8$ & 1 & 1 & 1 & 1 & 3 & 3 \\
\hline $\mathrm{H} 9$ & 12 & 10 & 9 & 9 & 12 & 12 \\
\hline $\mathrm{H} 10$ & 8 & 8 & 8 & 8 & 13 & 6 \\
\hline $\mathrm{H} 11$ & 5 & 5 & 6 & 6 & 4 & 4 \\
\hline $\mathrm{H} 12$ & 11 & 12 & 13 & 13 & 11 & 10 \\
\hline $\mathrm{H} 13$ & 6 & 6 & 7 & 7 & 9 & 9 \\
\hline
\end{tabular}




\section{Tab. 4: \\ Ranking of the influence of elements of structural capital on the sustainable development of enterprises in Poland}

\begin{tabular}{c|c|c|c|c|c|c}
\multirow{2}{*}{$\begin{array}{c}\text { Structural capital } \\
\text { elements }\end{array}$} & \multicolumn{6}{|c|}{ Size of enterprise } \\
\cline { 2 - 7 } & \multicolumn{2}{|c|}{ Small } & \multicolumn{2}{c}{ Medium } & \multicolumn{2}{c}{ Large } \\
\cline { 2 - 7 } & CoG & Median & CoG & Median & CoG & Median \\
\hline S1 & 1 & 1 & 1 & 1 & 4 & 4 \\
\hline S2 & 4 & 4 & 4 & 4 & 3 & 3 \\
\hline S3 & 5 & 5 & 5 & 5 & 5 & 5 \\
\hline S4 & 3 & 3 & 2 & 2 & 1 & 1 \\
\hline S5 & 2 & 2 & 3 & 3 & 2 & 2 \\
\hline
\end{tabular}

\section{Tab. 5:}

Ranking of the influence of elements of relational capital on the sustainable development of enterprises in Poland

\begin{tabular}{c|c|c|c|c|c|c}
\multirow{2}{*}{$\begin{array}{c}\text { Relational capital } \\
\text { elements }\end{array}$} & \multicolumn{6}{|c|}{ Size of enterprise } \\
\cline { 2 - 7 } & \multicolumn{2}{|c|}{ Small } & \multicolumn{2}{c}{ Medium } & \multicolumn{2}{c}{ Large } \\
\cline { 2 - 7 } & CoG & Median & CoG & Median & CoG & Median \\
\hline R1 & 2 & 2 & 2 & 2 & 3 & 3 \\
\hline R2 & 5 & 5 & 5 & 5 & 4 & 4 \\
\hline R3 & 4 & 4 & 4 & 4 & 5 & 5 \\
\hline R4 & 6 & 6 & 6 & 6 & 6 & 6 \\
\hline R5 & 3 & 3 & 3 & 3 & 2 & 2 \\
\hline R1 & 1 & 1 & 1 & 1 & 1 & 1 \\
\hline
\end{tabular}

Source: own

large enterprises. Kendall's tau-b compliance coefficients were $\tau=0.949$ and $\tau=0.974$ respectively. The values of these statistics mean that there is no statistically significant differentiation between the positions of human capital elements in the obtained rankings, both in the group of small and large enterprises.

\section{Conclusions}

The research clearly indicates that the majority of enterprises in Poland do neither formulate nor implement intellectual capital management strategies. However, this does not mean that company managers are not aware of the essence and significance of intellectual capital. Just over $2 / 3$ of the surveyed small and mediumsized enterprises, have declared knowledge in the field of intellectual capital. The share of positive answers in the group of enterprises employing more than 250 employees was even higher and reached $82 \%$. It is worth observing that managers of large enterprises are less likely than managers of medium-sized enterprises to base their decisions and actions on intellectual capital management strategies. The highest percentage $-30 \%$ - of positive responses has been recorded at medium-sized enterprises. It is worth highlighting how commonly intellectual capital is measured at enterprises. Measuring intellectual capital is chiefly done by companies employing fewer than 50 employees (nearly $10 \%$ of positive answers), whereas almost $30 \%$ of positive answers come from those that measure its elements. The distribution of answers in the group of medium and large enterprises was almost identical, i.e. slightly more than $5 \%$ of companies measure intellectual capital and slightly more than $1 / 4$ of enterprises declare measuring its some of its elements. Measurement is an essential element of effective intellectual capital management, and its results should guide the development of this capital. Knowledge about the individual 
components of intellectual capital can be used to formulating the company's strategy and identifying those resources that are most important and should be developed, or created and acquired in the case of missing assets.

Knowing which elements of intellectual capital have the greatest impact on business sustainability allows a better understanding of the relationships between intellectual capital and business sustainability. The assessment of the impact of the individual elements of human capital on the sustainable development of enterprises carried out in the article indicated that, according to managers of small companies, the most important factors are: honesty, reliability and skills of the employees. According to managers of mediumsized enterprises, in addition to honesty, it is the skills and knowledge of employees that have the greatest impact on the sustainable development of enterprises. Managers of large enterprises primarily indicated employees' knowledge, followed by their skills and integrity. Therefore, a high consistency of responses can be clearly observed, especially between managers of medium and large company. The employees' knowledge and skills are the basis for enterprises' innovation in the implementation of new, more environmentally friendly technologies. Companies are ecologically responsible for resource consumption, emissions, waste, and sewage generation. By implementing eco-investments, enterprises can reduce the costs of their operations and increase their long term competitiveness. As a result of rationalizing the use of water, energy, raw materials, and reducing the emission of pollutants and the amount of generated waste, enterprises incur lower costs related to fees for using the environment and penalties for violating the conditions of using it. Moreover, the change in the way companies operate towards business sustainability is the public's sensitivity to social and environmental issues. Growing ecological awareness of consumers forces entrepreneurs to take pro-ecological actions and modify their offer towards goods and services with a lower negative impact on the environment and consumer health. Besides, companies that treat environmental protection as an organizational culture element improve their image and market position. Improving the company's image is also fostered by pro-social initiatives, e.g., those related to improving the quality of life of the local community or caring for the well-being of employees. The results of the obtained research are all the more surprising in this context. What could be a cause for concern, especially in the context of the current situation on the labor market and difficulties in retaining employees, could be the low significance attached to employee satisfaction in large enterprises. It is wellestablished that an employee satisfied with their work is an employee displaying a higher level of commitment and loyalty, often also with fewer absences from work. According to the managers of medium-sized enterprises, wellbeing is the least important of the 13 factors of human capital. This could be surprising because the concept of employee well-being is part of the concept of sustainable development and corporate social responsibility. It is also a key element of each individual's quality of life.

In terms of structural capital, the most important, in the opinion of managers of small and medium-sized companies, is the technical infrastructure. According to the management of large enterprises, this is not as important as the organizational culture. Regardless of the size of the enterprise, managers agreed that intellectual property is least important for the company's sustainable development.

Between responses pertaining to the significance of relational capital elements the smallest differentiation of responses can be observed among enterprises of all sizes. Respondents agreed that the most important from the point of view of the development of their enterprise is their reputation and image on the market, whereas the least important are relations with science and research units.

All in all, it can be stated that the differentiation of the responses of managers based on the size of the enterprise was not statistically significant. Using the classical chi-squared test, all hypotheses have been confirmed, which concerned the lack of influence of the size of an enterprise, measured by the number of employees, on the responses given by managers and their opinions.

Future studies can go further into detail and investigate the relationship of individual dimension of social capital with individual dimension of sustainability. Further research also will investigate the relationship between the answers given by the respondents and the sector of the economy in which the enterprise operates. 


\section{References}

Abdullah, N. N., \& Othman, M. B. (2019). Effects of Intellectual Capital on the Performance of Malaysian Food and Beverage Small and Medium-Sized Enterprises. International Journal of Civil Engineering and Technology, 10(02), 135-143.

Aji, R. H. S., \& Kurniasih, K. (2015). The Intellectual Capital Effect on Financial Performances at Islamic Insurance. Al-lqtishad: Jurnal IImu Ekonomi Syariah (Journal of Islamic Economics), 7(2), 181-196. https://doi. org/10.15408/ijies.v7i2.1696

Akhtar, C. S., Ismail, K., Ndaliman, M. A., Hussain, J., \& Haider, M. (2015). Can Intellectual Capital of SMEs Help in Their Sustainability Efforts. Journal of Management Research, 7(2), 82-97. https://doi.org/10.5296/ jmr.v7i2.6930

Arifin, J. (2016). Corporate Governance and Intellectual Capital on Financial Performance of Bank Sector Companies: Indonesia Stock Exchange 2008-2012. Journal of Administrative Sciences and Policy Studies, 4(1), 61-82. https://doi.org/10.15640/jasps.v4n1a4

Arshad, M. Z., \& Arshad, D. (2018). Intellectual capital and SME's performance in Pakistan: The role of environmental turbulence. International Journal of Entrepreneurship, 22(1S).

Aseanty, D. (2016). Intellectual Capital and Sustainable Growth in Small and Medium Enterprises in Indonesia. OIDA International Journal of Sustainable Development, 9(10), 41-50.

Aymen, R. A., Alhamzah, A., \& Bilal, E. (2019). A multi-level study of influence financial knowledge management small and medium enterprises. Polish Journal of Management Studies, 19(1), 21-31. https://doi.org/10.17512/ pjms.2019.19.1.02

Barbieri, J. C., de Vasconcelos, I. F. G., Andreassi. T., \& de Vasconcelos, F. C. (2010). Inovação e sustentabilidade: novos modelos e proposições. Revista de Administração de Empresas, 50(2), 146-154. https://doi. org/10.1590/S0034-75902010000200002

Bontis, N. (2002). Assessing Knowledge Assets: A Review of the Models Used To Measure Intellectual Capital. International Journal of Management Reviews, 3(1), 41-60. https://doi.org/10.1111/1468-2370.00053

Bontis, N., Keow, W. C. C., \& Richardson, S. (2000). Intellectual capital and business performance in Malaysian industries. Journal of Intellectual Capital, 1(1), 85-100. https://doi. org/10.1108/14691930010324188

Bounfour, A., \& Edvinsson, L. (2005). Intellectual Capital for Communities - Nations, Regions and Cities. Oxford: ButterworthHeinemann.

Cabrita, M., \& Vaz, J. (2006). Intellectual Capital and Value Creation: Evidence from the Portuguese Banking Industry. The Electronic Journal of Knowledge Management, 4(1), 11-20.

Chen, Y. S. (2008). The Positive Effect of Green Intellectual Capital on Competitive Advantages of Firms. Journal of Business Ethics, 77(1), 271-286. https://doi.org/10.1007/ s10551-006-9349-1

Chen, M. C., Cheng, S. J., \& Hwang, Y. (2005). An empirical investigation of the relationship between intellectual capital and firms' market value and financial performance. Journal of Intellectual Capital, 6(2), 159-176. https://doi.org/10.1108/14691930510592771

Chen, Y. S., Lai, S. B., \& Wen, C. T. (2006). The Influence of Green Innovation Performance on Corporate Advantage in Taiwan. Journal of Business Ethics, 67(4), 331-339. https://doi. org/10.1007/s10551-006-9025-5

Chen, G., \& Pham, T. T. (2001). Introduction to Fuzzy Sets, Fuzzy Logic and Fuzzy Control Systems. Boca Raton, FL: CRC Press LLC.

Choi, S., \& Ng, A. (2011). Environmental and economic dimensions of sustainability and price effects on consumer responses. Journal of Business Ethics, 104(2), 269-282. https://doi.org/10.1007/s10551-011-0908-8

Claver-Cortés, E., Zaragoza-Sàez, P., Molina-Manchòn, H., \& Ubeda-Garcìa, M. (2015). Intellectual capital in family firms: Human capital identification and measurement. Journal of Intellectual Capital, 16(1), 199-233. https://doi.org/10.1108/JIC-04-2014-0046

Cowan, K., \& Guzman, F. (2020). How CSR reputation. sustainability signals. and countryof-origin sustainability reputation contribute to corporate brand performance: An exploratory study. Journal of Business Research, 117, 683-693. https://doi.org/10.1016/j. jbusres.2018.11.017

Dal Mas, F. (2019). The Relationship Between Intellectual Capital and Sustainability: An Analysis of Practitioner's Thought. In F. Matos, V. Vairinhos, P. Seling, \& L. Edvinsson (Eds.), Intellectual Capital Management as a Driver of Sustainability (pp. 11-24). Cham: 
Springer. https://doi.org/10.1007/978-3-31979051-0_2

Drucker, P. F. (1988). The coming of the new organization. Harvard Business Review, $66,45-53$.

Dženopoljac, V., Janoševic, S., \& Bontis, N. (2016). Intellectual Capital and Financial Performance in the Serbian ICT industry. Journal of Intellectual Capital, 17(2), 373-396. https://doi.org/10.1108/jic-07-2015-0068

Edvinsson, L., \& Malone, M. (1997). Intellectual capital: Realising your company's true value by finding its hidden brainpower. New York, NY: Harper Collins.

Firer, S., \& Mitchell Williams, S. (2003). Intellectual capital and traditional measures of corporate performance. Journal of Intellectual Capital, 4(3), 348-360. https://doi. org/10.1108/14691930310487806

Goodland, R. (1995). The concept of environmental sustainability. Annual Review of Ecology and Systematics, 26, 1-24. https://doi. org/10.1146/annurev.es.26.110195.000245

Grant, R. M. (1996). Toward a knowledgebased theory of the firm. Strategic Manage Journal, 17(S2), 109-122. https://doi. org/10.1002/smj.4250171110

Hayton, J. C. (2005). Competing in the new economy: The effect of intellectual capital on corporate entrepreneurship in high-technology new ventures. R\&DManagement, 35(2), 137-155. https://doi.org/10.1111/j.1467-9310.2005.00379.x

Jordão, R. V. D., \& Almeida, V. R. d. (2017). Performance measurement, intellectual capital \& financial sustainability. Journal of Intellectual Capital, 18(3), 643-666. https://doi.org/10.1108/ JIC-11-2016-0115

Khan, Y. K., Marzuk, S. Z. S., \& Arshad, A. S. M. (2018). The Influence of Intellectual Capital on Product. Process and Administration Innovation in the SMEs Context. Journal of Management Info, 5(3), 1-7. https://doi. org/10.31580/jmi.v5i3.79

Klir, G. J., \& Yuan, B. (1995). Fuzzy Sets and Fuzzy Logic. Theory and Applications. Upper Saddle River, NJ: Prentice Hall.

Lubiano, M. A., de Sáa, S. d. I. R., Montenegro, M., Sinova, B., \& Gil, M. A. (2016). Descriptive analysis of responses to items in questionnaires. Why not using a fuzzy rating scale? Information Sciences, 360, 131-148. https://doi.org/10.1016/j.ins.2016.04.029

Maditinos, D., Chatzoudes, D., Tsairidis, C., \& Theriou, G. (2011). The Impact of
Intellectual Capital on Firms Market Value and Financial Performance. Journal of Intellectual Capital, 12(1), 132-151. https://doi. org/10.1108/14691931111097944

Massaro, M., Dumay, J., Garlatti, A., \& Dal Mas, F. (2018). Practitioners' views on intellectual capital and sustainability: From a performance-based to a worth-based perspective. Journal of Intellectual Capital, 19(2), 367-386. https://doi.org/10.1108/JIC-022017-0033

Martinez García de Leaniz, P., \& Rodríguez del Bosque, I. (2013). Intellectual capital and relational capital: The role of sustainability in developing corporate reputation. Intangible Capital, 9(1), 262-280. https://doi.org/10.3926/ ic. 378

Mehralian, G., Rasekh, H. R., Akhavan, P., \& Sadeh, M. R. (2012). The Impact of Intellectual Capital Efficiency on Market Value: An Empirical Study from Iranian Pharmaceutical Companies. Iranian Journal of Pharmaceutical Research, 11(1), 195-207.

Mertins, K., \& Orth, R. (2012). Intellectual Capital and the Triple Bottom Line: Overview, Concepts and Requirements for an integrated Sustainability Management System. In J. Surakka (Ed.), Proceedings of the 4th European Conference on Intellectual Capital (pp. 516-526). Helsinki: Academic Conferences and Publishing International Limited.

Mondal, A. (2016). Application of Modified Model for Measuring Intellectual Capital Performance. International Journal of Research in Finance and Marketing, 6(11), 19-30.

Mukherjee, T., \& Sen, S. S. (2019). Intellectual Capital and Corporate Sustainable Growth: The Indian Evidence. Journal of Business, Economics and Environmental Studies, 9(2), 5-15. https://doi.org/10.13106/ jbees.2019.vol9.no2.5

Munck, L., Bansi, A. C., \& Galleli, B. (2016). Sustentabilidade em Contexto Organizacional: uma análise comparativa de modelos que propõem trajetórias para sua gestão. Revista de Ciências da Administração, 18(44), 91-110. https://doi.org/10.5007/21758077.2016v18n44p91

Nassar, S. (2018). The Impact of Intellectual Capital on Corporate Performance of IT Companies: Evidence from Bursa Istanbul. Journal of Accounting and Applied Business Research, 1(3), 1-9. https://doi.org/10.51325/ ijbeg.v1i3.17 
Omar, M. K., Yusoff, Y. M., \& Zaman, M. D. K. (2017). The Role of Green Intellectual Capital on Business Sustainability. World Applied Sciences Journal, 35(12), 2558-2563. https://doi.org/10.5829/idosi.wasj.2017.2558.2563

Parchami, A., Nourbakhsh, M., \& Mashinchi, M. (2017). Analysis of variance in uncertain environments. Complex and Intelligent Systems, 3(3), 189-196. https://doi. org/10.1007/s40747-017-0046-8

Parchami, A. (2018). One-Way Analysis of Variance Based on Triangular Fuzzy Numbers. Retrieved August, 2019, from https://cran.rproject.org/web/packages/ANOVA.TFNs/ ANOVA.TFNs.pdf

Pew Tan, H., Plowman, D., \& Hancock, P. (2007). Intellectual Capital and Financial Returns of Companies. Journal of Intellectual Capital, 8(1), 76-95. https://doi. org/10.1108/14691930710715079

Rehman, W. U., Rehman, H. U., Usman, M., \& Asghar, N. (2012). A Link of intellectual capital performance with corporate performance: Comparative study from banking sector in Pakistan. International Journal of Business and Social Science, 3(12), 313-321.

Roos, G., \& Roos, J. (1997). Measuring your company's intellectual performance. Long Range Planning, 30(3), 413-426. https://doi. org/10.1016/S0024-6301(97)90260-0

Sheth, J. N., Sethia, N. K., \& Srinivas, S. (2011). Mindful consumption: A customercentric approach to sustainability. Journal of the Academy Marketing Science, 39(1), 21-39. https://doi.org/10.1007/s11747-010-0216-3

Shiu, H. J. (2006). The application of the value added intellectual coefficient to measure corporate performance: Evidence from technological firms. International Journal of Management, 23(2), 356-365.
Stewart, T. A. (2001). The Wealth of Knowledge. Intellectual Capital and the TwentyFirst Century Organization. London: Nicholas Brealey Publishing.

Suciu, M. C., \& Năsulea, D. F. (2019). Intellectual capital and creative economy as key drivers for competitiveness towards a smart and sustainable development: challenges and opportunities for cultural and creative communities. In F. Matos, V. Vairinhos, P. Seling, \& L. Edvinsson (Eds.), Intellectual Capital Management as a Driver of Sustainability (pp. 67-97). Berlin/Heidelberg: Springer.

Sumedrea, S. (2013). Intellectual Capital and Firm Performance: A Dynamic Relationship in Crisis Time. Procedia Economics and Finance, 6, 137-144. https://doi.org/10.1016/ S2212-5671(13)00125-1

Todingbua, M. A., Haerani, S., \& Ramli, A. (2018). The Influence of Intellectual Capital Small and Medium Enterprises towards Productivity through Managerial Skills in Makassar. Journal of Economics Theory, 12(1), 1-7. https://doi.org/10.36478/jeth.2018.1.7

Wasiluk, L. K. (2013). Beyond eco-efficiency: Understanding CS through the IC practice lens. Journal of Intellectual Capital, 14(1), 102-126. https://doi.org/10.1108/14691931311289048

$\mathrm{Xu}$, J., \& Wang, B. (2018). Intellectual Capital. Financial Performance and Companies' Sustainable Growth: Evidence from the Korean Manufacturing Industry. Sustainability, 10(12), 4651. https://doi.org/10.3390/su10124651

Yusoff, Y. M., Omar, M. K., Kamarul, M. D., \& Samad, Z. S. (2019). Do all elements of green intellectual capital contribute toward business sustainability? Evidence from the Malaysian context using the Partial Least Squares method. Journal of Cleaner Production, 234, 626-637. https://doi.org/10.1016/j.jclepro.2019.06.153 


\section{Appendix}

\section{Tab. A1: The significance of human capital for the development of enterprises}

\begin{tabular}{|c|c|c|c|c|c|c|c|c|c|}
\hline \multirow{3}{*}{$\begin{array}{c}\text { Human } \\
\text { capital } \\
\text { elements }\end{array}$} & \multicolumn{9}{|c|}{ Size of enterprise } \\
\hline & \multicolumn{3}{|c|}{ Small } & \multicolumn{3}{|c|}{ Medium } & \multicolumn{3}{|c|}{ Large } \\
\hline & $a^{*}$ & $\mathbf{b}^{* *}$ & $\mathrm{c}^{* * *}$ & $a$ & $\mathbf{b}$ & c & $a$ & b & c \\
\hline $\mathrm{H} 1$ & 5.189 & 8.498 & 9.817 & 5.305 & 8.641 & 9.908 & 5.752 & 9.090 & 9.848 \\
\hline $\mathrm{H} 2$ & 5.411 & 8.721 & 9.889 & 5.386 & 8.722 & 9.933 & 5.600 & 8.938 & 9.848 \\
\hline $\mathrm{H} 3$ & 4.564 & 7.858 & 9.684 & 4.597 & 7.932 & 9.701 & 4.238 & 7.571 & 9.848 \\
\hline $\mathrm{H} 4$ & 4.946 & 8.258 & 9.891 & 4.972 & 8.307 & 9.976 & 4.844 & 8.027 & 9.697 \\
\hline $\mathrm{H} 5$ & 4.777 & 8.091 & 9.838 & 4.416 & 7.750 & 9.782 & 4.163 & 7.329 & 9.667 \\
\hline $\mathrm{H} 6$ & 5.475 & 8.793 & 9.935 & 5.243 & 8.578 & 10.000 & 4.390 & 7.723 & 10.000 \\
\hline $\mathrm{H} 7$ & 5.612 & 8.926 & 9.943 & 5.482 & 8.819 & 10.000 & 5.233 & 8.569 & 10.000 \\
\hline $\mathrm{H} 8$ & 4.615 & 7.937 & 9.852 & 4.667 & 8.001 & 9.835 & 3.964 & 7.297 & 9.841 \\
\hline $\mathrm{H} 9$ & 4.489 & 7.807 & 9.820 & 4.407 & 7.740 & 9.849 & 4.662 & 7.997 & 9.833 \\
\hline $\mathrm{H} 10$ & 4.763 & 8.074 & 9.890 & 4.648 & 7.982 & 9.977 & 3.964 & 7.139 & 9.364 \\
\hline $\mathrm{H} 11$ & 5.081 & 8.405 & 9.943 & 4.903 & 8.237 & 10.000 & 4.995 & 8.330 & 10.000 \\
\hline $\mathrm{H} 12$ & 4.481 & 7.802 & 9.844 & 4.368 & 7.701 & 9.831 & 4.070 & 7.403 & 9.629 \\
\hline $\mathrm{H} 13$ & 5.005 & 8.309 & 9.871 & 4.744 & 8.079 & 9.931 & 4.163 & 7.496 & 9.666 \\
\hline
\end{tabular}

Note: ${ }^{*} a$ - left spread of fuzzy number, ${ }^{* *} b$ - the center of a fuzzy number area, ${ }^{* * *} c$ - right spread of fuzzy number.

\section{Tab. A2: The significance of structural capital for the development of enterprises}

\begin{tabular}{c|c|c|c|c|c|c|c|c|c}
\multirow{2}{*}{$\begin{array}{c}\text { Structural } \\
\text { capital } \\
\text { elements }\end{array}$} & \multicolumn{9}{|c|}{ Size of enterprise } \\
\cline { 2 - 11 } & \multicolumn{3}{|c|}{ Small } & \multicolumn{3}{c|}{ Medium } & \multicolumn{3}{c}{ Large } \\
\cline { 2 - 11 } & $\mathbf{a}^{*}$ & $\mathbf{b}^{* *}$ & $\mathbf{c}^{\star * *}$ & $\mathbf{a}$ & $\mathbf{b}$ & $\mathbf{c}$ & $\mathbf{a}$ & $\mathbf{b}$ & $\mathbf{c}$ \\
\hline S1 & 4.180 & 7.477 & 9.698 & 4.471 & 7.805 & 9.860 & 3.935 & 7.268 & 9.848 \\
\hline S2 & 3.990 & 7.282 & 9.466 & 4.221 & 7.555 & 9.624 & 4.238 & 7.571 & 9.848 \\
\hline S3 & 2.957 & 6.101 & 8.698 & 3.279 & 6.536 & 8.929 & 3.552 & 6.885 & 9.332 \\
\hline S4 & 4.010 & 7.314 & 9.725 & 4.334 & 7.668 & 9.779 & 4.599 & 7.933 & 9.682 \\
\hline S5 & 4.120 & 7.412 & 9.662 & 4.315 & 7.649 & 9.788 & 4.541 & 7.876 & 9.545 \\
\hline
\end{tabular}

Source: own

Note: ${ }^{*} a-$ left spread of fuzzy number, ${ }^{* *} b$ - the center of a fuzzy number area, ${ }^{* * *} c$ - right spread of fuzzy number. 


\section{Business Administration and Management}

Tab. A3: The significance of structural capital for the development of enterprises

\begin{tabular}{c|c|c|c|c|c|c|c|c|c}
\multirow{2}{*}{$\begin{array}{c}\text { Relational } \\
\text { capital } \\
\text { elements }\end{array}$} & \multicolumn{9}{|c}{ Size of enterprise } \\
\cline { 2 - 11 } & \multicolumn{4}{|c}{ Small } & \multicolumn{3}{c}{ Medium } & \multicolumn{3}{c}{ Large } \\
\cline { 2 - 11 } & $\mathbf{a}^{*}$ & $\mathbf{b}^{* *}$ & $\mathbf{c}^{* * *}$ & $\mathbf{a}$ & $\mathbf{b}$ & $\mathbf{c}$ & $\mathbf{a}$ & $\mathbf{b}$ & $\mathbf{c}$ \\
\hline R1 & 5.410 & 8.723 & 9.930 & 5.190 & 8.503 & 9.862 & 4.281 & 7.615 & 9.682 \\
\hline R2 & 3.173 & 6.352 & 8.883 & 3.564 & 6.845 & 9.191 & 3.330 & 6.662 & 9.411 \\
\hline R3 & 3.338 & 6.382 & 8.703 & 3.844 & 6.958 & 9.018 & 3.330 & 6.466 & 9.018 \\
\hline R4 & 1.640 & 4.365 & 7.377 & 2.297 & 5.216 & 7.956 & 2.442 & 5.552 & 8.219 \\
\hline R5 & 4.417 & 7.653 & 9.585 & 4.408 & 7.742 & 9.664 & 4.309 & 7.643 & 9.804 \\
\hline R6 & 5.627 & 8.938 & 9.924 & 5.634 & 8.971 & 9.977 & 4.916 & 8.251 & 9.841 \\
\hline & & & & & & & & \multicolumn{3}{c}{ Source: own }
\end{tabular}

Note: ${ }^{*} a-$ left spread of fuzzy number, ${ }^{* *} b-$ the center of a fuzzy number area, ${ }^{* *} \mathrm{c}-$ right spread of fuzzy number. 